Editorial

\title{
The Takahashi-Bassett Era of Mineral Physics at Rochester in the 1960s
}

\author{
William A. Bassett
}

Department of Earth and Atmospheric Sciences, Cornell University, Ithaca, NY 14853, USA; wab7@cornell.edu

Received: 16 March 2020; Accepted: 9 April 2020; Published: 12 April 2020

\begin{abstract}
The late Taro Takahashi earned a particularly well-deserved reputation for his research at Lamont Geological Observatory on carbon dioxide and its transfer between the atmosphere and the oceans. However, his accomplishments in Mineral Physics, the field embracing the high-pressure-high-temperature properties of materials, has received less attention in spite of his major contributions to this emerging field focused on the interiors of Earth and other planets. In 1963, I was thrilled when he was offered a faculty position in the Geology Department at the University of Rochester, where I had recently joined the faculty. Taro and I worked together for the next 10 years with our talented students exploring the blossoming field just becoming known as Mineral Physics, the name introduced by Orson Anderson and Ed Schreiber, who were also engaged in measuring physical properties at high pressures and temperatures. While their specialty was ultrasonic velocities in minerals subjected to high pressures and temperatures, ours was the determination of crystal structures, compressibilities, and densities of such minerals as iron, its alloys, and silicate minerals, especially those synthesized at high-pressure, such as silicates with the spinel structure. These were materials expected to be found in the Earth's interior and could therefore provide background for the interpretation of geophysical observations.
\end{abstract}

Keywords: mineral physics; earth interior; diamond anvil cell; high pressure

\section{Introduction}

Geophysics, the study of the macro properties of Earth, was very active in the mid-twentieth century. Such properties included seismic signals (at all depths), gravity, magnetism, moments of inertia, free oscillations, and heat flow. The study of meteorites and volcanic rocks provided clues about planetary interiors and suggested the most likely compositions. At the same time, it was becoming clear that there was not enough understanding of the most fundamental properties of matter at the conditions existing in the interiors of Earth and other planets, properties that could possibly be measured in laboratories equipped with apparatus capable of achieving those pressures and temperatures.

Taro Takahashi and I were good friends while we were graduate students in geology at Columbia University in the latter part of the 1950s. When he and I had finished and defended our PhD theses, he was invited by Maurice Ewing, Director of Columbia University's Lamont Geological Observatory, to undertake a post-doctoral position to participate in excursions around the oceans on the Vema, Lamont's research vessel. I once visited him at Lamont and climbed to the crow's nest on the Vema, an adventure which gave me a taste of what it must have been like for him to go to sea and experience the excitement of making valuable contributions to oceanography. On the Vema, Taro collected samples of sea water and analyzed them in the Vema chemistry lab immediately after they were collected. Doc Ewing's primary research interest, and what he is most famous for, was seismic exploration of the oceans and the rocks in the floor under the oceans. Over meals, while both were pursuing their research interests on the Vema, Taro would ask Doc about what the seismic studies were revealing. One day, 
as he learned more about seismic research, he asked Doc what he thought caused the Mohorovičić discontinuity (Moho for short) that separates rocks conducting seismic signals at $\sim 6 \mathrm{~km}$ per second from deeper rocks conducting seismic signals at $\sim 8 \mathrm{~km}$ per second, and has a depth that varies dramatically under oceans and continents. It is a major feature of the earth's interior and was attracting a lot of attention which eventually led to the theory of plate tectonics, the great paradigm shift in geology. Doc replied that there were two possible explanations, either a change in composition or a change in physical properties. It was clear to both that, at that time, the compositions and physical properties were simply too poorly understood to answer the question adequately.

\section{End of Post-Doc Years and Chance to Pursue Research on Earth's Interior}

When Taro's two-year post-doc appointment was up, he decided it was time to find a position at a research university where he might be able to find a more definitive answer to the question he had asked Doc Ewing. He was convinced that finding an answer to that and numerous other questions about Earth's interior would depend on more accurate data regarding the properties of minerals at the pressures and temperatures in the Earth's interior, and that would need to be done in a lab with special equipment. He accepted a faculty appointment at Alfred University in Upstate New York in around 1959. One of the first things Taro did was write a letter to Percy Bridgman, Professor of Physics at Harvard University and considered the father of high-pressure research, to request some of his papers. Bridgman replied with an extensive collection of his reprints. As it turned out, Bridgman had sent that valuable collection to Taro shortly before he died. It was only a few years after that a research team at the General Electric Research Lab succeeded in synthesizing diamond using the belt apparatus invented by Tracy Hall. When General Electric executives told Tracy that the belt design belonged to GE, Tracy left GE and returned to his hometown, Provo, Utah. There, he joined the Brigham Young University faculty, where he invented the tetrahedral multi-anvil press which was also able to synthesize diamond. It was a derivation of the tetrahedral multi-anvil apparatus that Taro installed in his lab at Alfred University [1] (Figure 1). He and his students analyzed the physical properties of minerals at high pressures, especially minerals with a composition believed to be the same as, or similar to, the components of the earth's interior.

Soon after I completed my thesis, I took a post-doc position in the Chemistry Department at Brookhaven National Laboratory measuring the ages of minerals from young volcanic rocks, a job made possible because two of the most sensitive mass spectrometers in the world resided there in Oliver Schaeffer's lab. This was very different from going to sea on the Vema, but was very exciting in other ways. When my post-doc appointment ended in 1961, I took a position in the Geology Department at the University of Rochester, not far from Alfred.

Shortly after I had settled into my new job, the chairman of the Geology Department, Bob Sutton, asked me who I thought the department should add to its faculty next. Without hesitation, I said, "Taro Takahashi". I, too, had installed equipment, a GE X-ray machine so I could study minerals; Taro seemed a perfect choice. Much to my pleasure, Bob took me seriously, and we invited Taro to pay us a visit. Shortly after that, Taro was offered a position in the Geology Department at Rochester and generous space to carry on his research into the effects of high pressure on minerals. Outfitting his lab with equipment, his move from Alfred to Rochester went well, except for one unfortunate incident. He brought with him the large plumber's vise (near the foreground in Figure 1) that he needed for some of his experiments. When the campus plumbers left after installing a badly needed sink, he realized that his vise was missing and could not be found anywhere. It was a serious loss but, at the same time, it was a source of amusement when we tried to imagine the plumbers asking each other if the vise could possibly have belonged to the new guy just moving in, and if he could possibly need a plumber's vise for his research. 


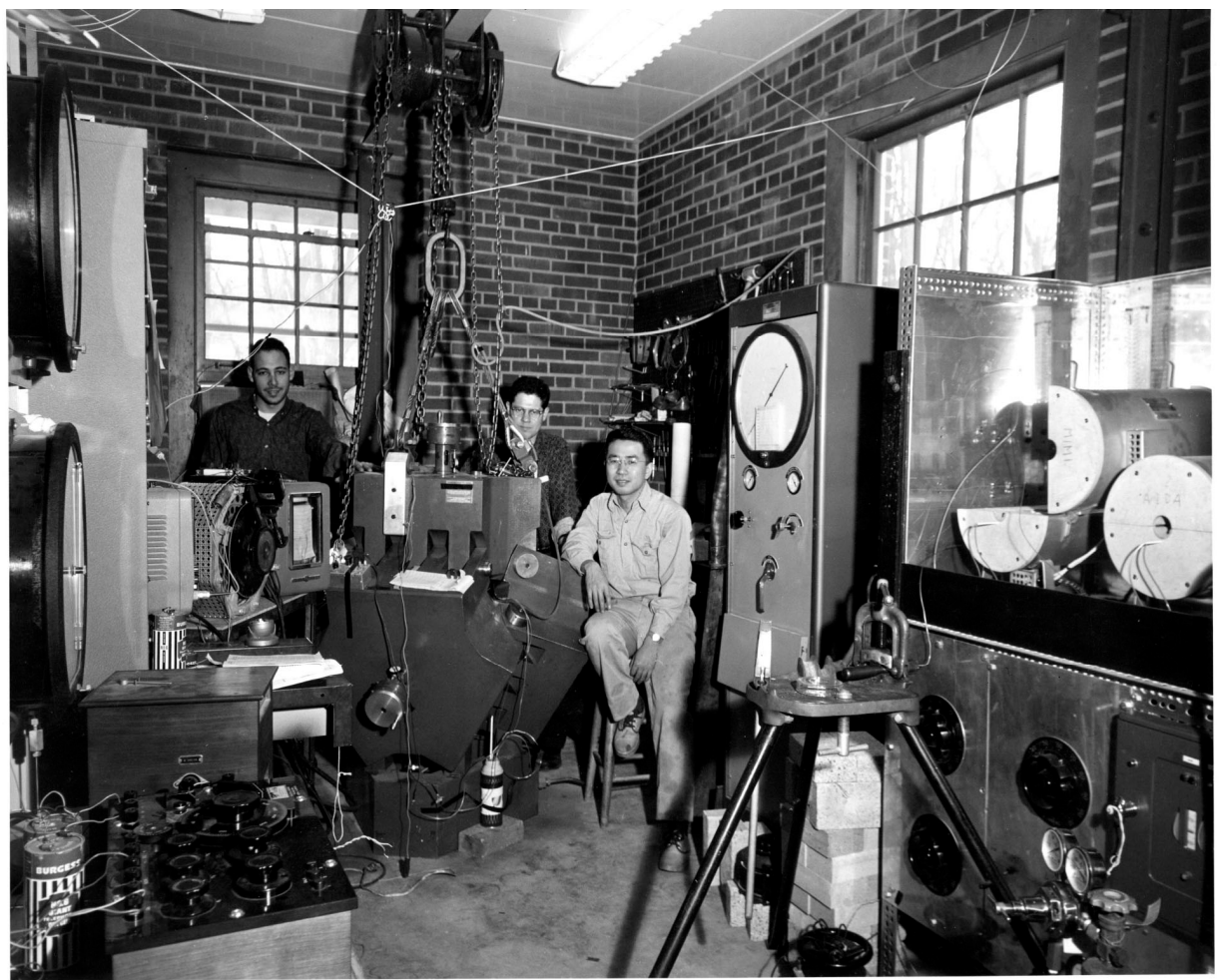

Figure 1. Alfred University, 1960: Taro Takahashi's high-pressure lab equipped with a tetrahedral multi-anvil apparatus. Taro is on the right and his graduate student at the time, Ed Schreiber, is in the center. It was shortly after this (about 1963) that Taro accepted an offer at the University of Rochester and continued his high-pressure research, while Ed moved to Lamont Geological Observatory as a member of the research faculty to pursue high-pressure experiments in the Mineral Physics laboratory of Orson Anderson. (Photo courtesy of Taro Takahashi and Bob Liebermann).

\section{Married Life and Friends}

I met Jane, my wife-to-be, soon after I moved to Rochester. She too was a geologist. We fell in love and married, and bought a farm in Churchville, a few miles west of Rochester and had our first child, Kari. Taro was a frequent visitor to the farm, where he became acquainted with Kari. They seemed to hit it off right away (Figure 2).

Taro met Elaine, his wife-to-be, at Rochester also. When he proposed to her, he gave her an engagement ring with a pearl and a diamond, suggesting that her passion for biology might join his passion for oceanography and high-pressure research. I had given Jane an engagement ring bearing two diamonds the same size. That must have been an omen as, in our case, I had not yet learned what kind of research I would be conducting for the rest of my life as a result of my collaboration with Taro. After they married, Taro and Elaine both became frequent visitors to our farm. Taro and I liked to write papers there, with me at the typewriter and Taro looking over my shoulders saying things like, "Isn't there a simpler way to say that?" or "How about inserting a reference here?". When he was not making comments like that, he was generating new ideas and new ways to convey them through print; I would keep typing, but then I would get to comment. There was no delete button on my typewriter, of course, just a rapid-firing $X$ key. Our pages often had many Xed out words, sometimes nine tenths of a page. However, I loved writing papers that way and I think he did too. It was exciting and fast (it was, after all, an electric typewriter). Taro and I produced 21 peer-reviewed papers with our students (see Appendix A). Computer aids to writing would have to wait, but we did make use of the primitive computers then available to help interpret data. 


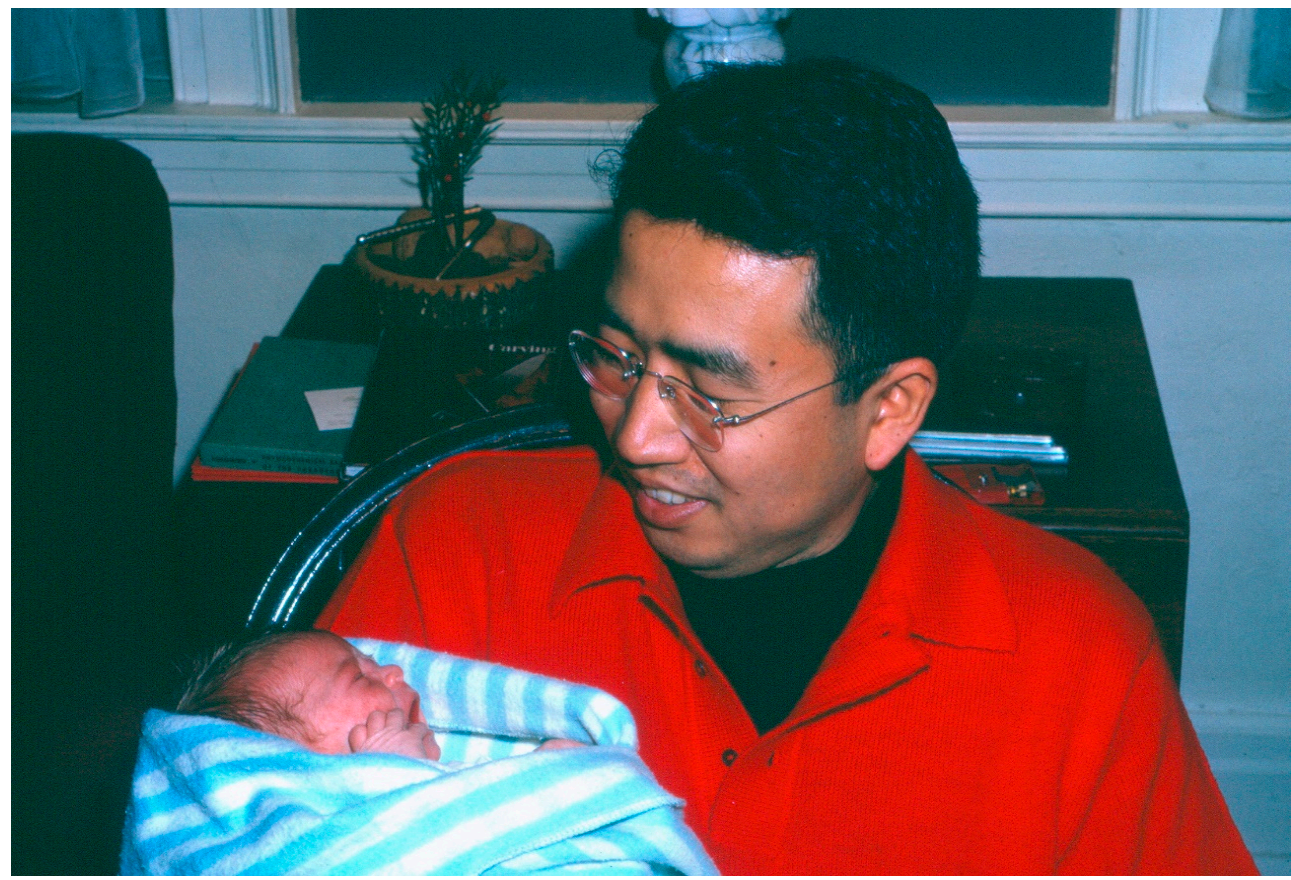

Figure 2. Taro was a frequent visitor to our farm a few miles west of Rochester. Here, he holds Kari, our first-born child. I'm not sure, of course, but he does look as if he might be telling her that someday she too may be a geologist. If so, he was right.

\section{The Diamond Anvil Cell}

Taro and I talked about the properties of minerals at very high pressures and temperatures and ways to extend the range of pressure and provide simultaneous temperature so we could use $X$-rays and other analytical techniques to examine their properties. One day, Taro came to my office, very excited about something, and said he had just seen a notice for a paper to be given in a few days at a conference in New York City, describing an instrument called a diamond anvil cell that would let a person look directly at a sample through the diamonds, using a microscope. That sounded too good to be true, and so we drove to New York City and listened to Alvin Van Valkenburg talk about the simple, beautiful, clever, little instrument and saw pictures of samples taken at high pressure [2]. If visible light could be used to observe samples at high pressures, why not X-rays? We introduced ourselves and made arrangements to pay a visit to Van's lab at the National Bureau of Standards in Washington, DC. One of the first things we learned there was that the idea of using X-rays had already been thought of and put to use by Charlie Weir, a member of the Bureau of Standard's high-pressure team [2]. Taro asked if they would object to having our machinist make a diamond anvil cell designed for use with X-rays, and they said that they did not object. I did not even know that we had a machinist. Fortunately, Taro knew a very able machinist, Phil Stook, on one of the upper floors of a large, drafty, old brick factory in Hornell, NY who used to make transmissions for army tanks but now did odd jobs for people.

Taro and I drove back from Washington to Rochester, marveling at the bright, new way that had just opened up before us. He was sure that Phil would be willing to tackle something as small as a diamond anvil cell, in spite of his earlier job. The first few cells that Phil made for us in that old brick factory worked perfectly [3]. However, there were many problems yet to be solved; my GE X-ray diffractometer was woefully inadequate for all the ideas we and our students were having, and so we purchased additional Norelco and Jarrell Ash X-ray machines, each with four ports and much better designed for use with X-ray film cameras. Needless to say, the samples were microscopic in size, as that was the only way to achieve the high pressures (up to 300 kilobars) that we hoped to go to. No manufacturers made collimators suitable for producing such a small $(\sim 0.1 \mathrm{~mm}) \mathrm{X}$-ray beam, 
and so we consulted nearby Corning Glass works. They sent us a boxful of empty thermometer stems of various sizes made of lead glass. They were perfect when we cut them to length. The best results were achieved after days (and nights) of exposure. Our students soon fell into a ritual of developing the films at the end of each week when they were finished with their classes and could measure the diffraction lines to solve for crystal structure and molar volume. The small X-ray films $(35 \times 35 \mathrm{~mm})$ were difficult to read accurately, especially with their dark backgrounds, due to the tiny sample sizes. We decided that focusing monochromatic sources would greatly improve the quality of our films. Although I found bent-crystal focusing monochromators for sale, there was no product for mounting them on our X-ray machines. So, I had Phil make a prototype box with $1 / 8^{\prime \prime}$ brass walls to hold and tune the monochromator and told him it must not leak any of the X-rays. When he had finished, he showed me that it could hold water without leaking. That was safer than I had expected, but I decided that a few of them for the most challenging samples would serve nicely. From then on, we had sharp lines that stood out from the lighter backgrounds.

Once we learned what a capable machinist Phil was, we got together and persuaded the Rochester Geology Department to hire Phil and find space so we could establish a machine shop to make more diamond anvil cells, but with ever changing designs as we came to realize just how versatile the instrument could be, as a result of its extraordinarily simple principle. Diagrams of just a few of the many different designs that evolved are shown in reference [4].

We made a great team because Taro had a strong background in solid-state physics, thermodynamics, and math, at which he was far more capable than I was. He befriended some of the faculty in the Physics Department, who provided help in interpreting our data. Taro was very good at guiding our students to squeeze as much information as possible from their data.

I, on the other hand, loved dreaming up new designs for the diamond anvil cell. There were so many possibilities and so much to be studied. I am very grateful for Taro's grasp of the need for lab measurements, and his ability to interpret our data and guide our students just as Orson Anderson at Lamont, at about the same time, contributed to our understanding of planetary interiors through ultrasonic measurements of elastic properties, and his guidance of such able colleagues as Bob Liebermann and Ed Schreiber.

\section{Research Results}

There are many interesting parameters to be measured as a function of pressure. Crystal structure is essential for determining molar volume which, in turn, is needed for determining densities. The effect of pressure on these very basic properties is needed for interpreting field observations resulting from geophysical research. Therefore, these properties seemed like the most important ones to start with, especially as we were bringing together X-ray diffraction (my specialty) and pressure (Taro's specialty).

Fortunately, the crystal structures of most of the samples we wanted to study were well known or simple enough that they were easily determined. Initially, we did not worry about the question of hydrostaticity, but we soon found that deviatoric stress could lead to inaccurate molar volume measurements. We adopted Alvin Van Valkenburg's gasketing method of immersing samples in a fluid pressure medium or a solid soft enough to introduce negligible deviatoric stress. We used X-ray diffraction patterns of $\mathrm{NaCl}$, or sometimes $\mathrm{Au}$, as the pressure marker. In fact, we, along with others, devoted much effort to making the $\mathrm{NaCl}$ pressure scale accurate. We wrote 22 papers, mostly on the isothermal compression of minerals important to the Earth's interior. Figure 3 shows the plots of molar volume versus pressure of four of the mineral phases that were of greatest interest at the time. 


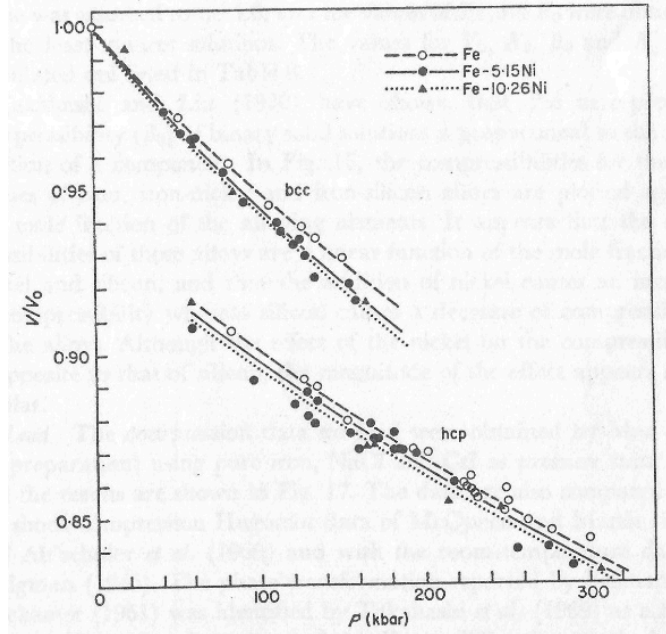

(a)

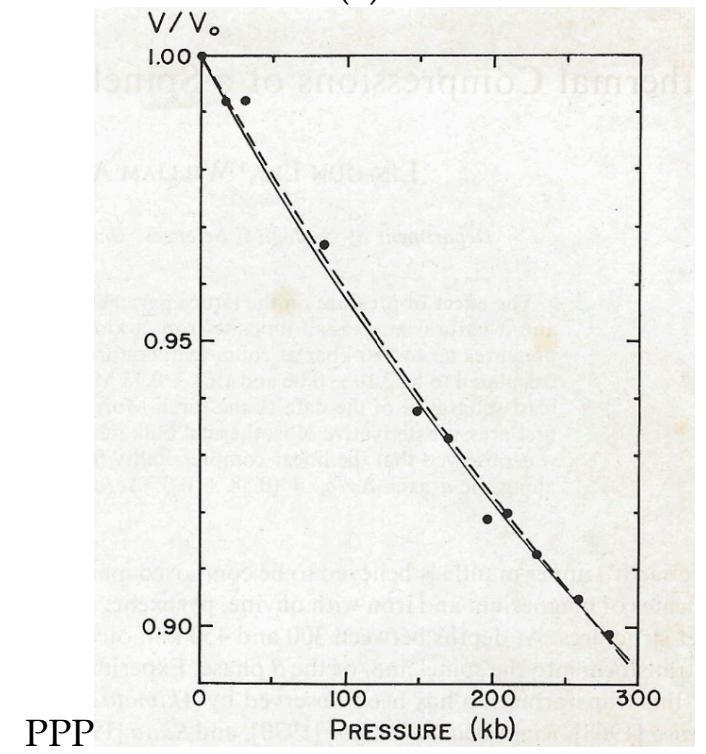

(c)

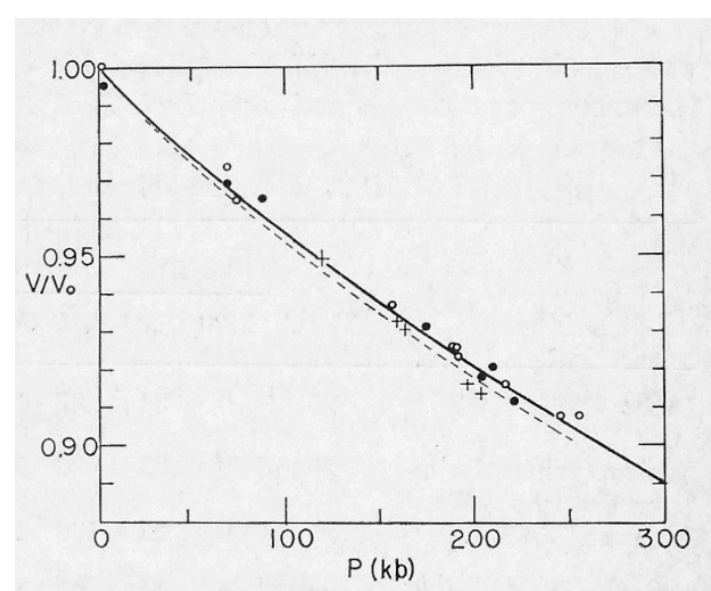

(b)

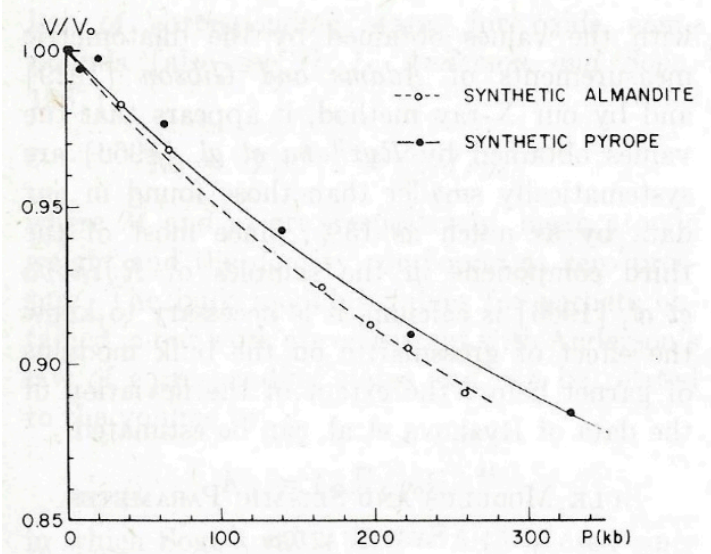

(d)

Figure 3. Four examples of early measurements of isothermal compression at $25^{\circ} \mathrm{C}$ of phases important for interpreting data concerning the Earth's interior using lattice parameters based on X-ray diffraction (a) Fe, Fe-5.15 Ni , Fe-10.26 Ni [5]; (b) Three spinel phases of synthesized $\mathrm{Fe}_{2} \mathrm{SiO}_{4}$ (open circles), $\mathrm{Fe}_{1.8} \mathrm{Mg}_{0.2} \mathrm{SiO}_{4}$ (pluses), $\mathrm{Fe}_{1.6} \mathrm{Mg}_{0.4} \mathrm{SiO}_{4}$ (closed circles) [6]; (c) Spinel phase of synthesized $\mathrm{Co}_{2} \mathrm{SiO}_{4}$ dashed and solid lines by two slightly different least-square fits [7]; (d) Two garnet compositions [8].

\section{High Temperatures Simultaneous with High Pressure}

One day in the mid-1960s, while Taro and I were having lunch at a local restaurant, we were discussing the desirability of being able to raise the temperature of our samples simultaneously with high pressure. Resistance heating was certainly a possibility, but the achievable temperatures would not get us very far into the Earth's interior. Taro said, "Maybe we could use a laser beam to heat our samples to higher temperatures while they are under pressure". Lasers were very new at that point, so new that when we discussed our idea with a faculty member in the Department of Physics at the University of Rochester, he commented that "Maybe lasers will have a use after all". The idea immediately appealed to me, but lasers were not something you could place an order for. I thought maybe it would be good to get some experience with resistance heating and collecting data at temperatures up to perhaps $\sim 800^{\circ} \mathrm{C}$. That was challenge enough, and it was only after Taro and I parted ways that I finally succeeded in coming up with a good design for resistance heating. A few 
years later, lasers became available and I visited the Howard Hughes Laser lab in California in 1968 with a diamond anvil cell loaded with graphite at high pressure. I shot the sample with their ruby laser and looked to see if the graphite had become transparent, indicating that it had transformed into diamond. It had not. Even though the test run was a failure, I was so convinced that Taro was right that I purchased the laser anyway. When I set it up in my lab and tried the experiment again, it failed again. The solution was easy, however. The diamond anvils were such good thermal conductors that the graphite simply was not hot enough for the transition. I mixed particles of graphite with $\mathrm{NaCl}$ and tried again. This time, the black particles of graphite not only became transparent, but they clearly had a very high refractive index that made them stand out from the salt. If a different sample was too transparent for the laser beam to heat it, graphite could be mixed with it to make it dark. Heating a sample by laser was an excellent way to promote phase transitions with kinetic barriers, like that of graphite to diamond. Most silicates of interest also had kinetic barriers and so the study of high-pressure phases of many silicates could benefit from laser heating. Measuring temperature, however, was a new challenge if pressure-temperature phase boundaries were to be determined or new phases were to be found. Blackbody emission spectra were the solution to that, as long as the sample was black or nearly black. Laser heating with more powerful YAG lasers became so intense that diamond particles in $\mathrm{NaCl}$ could be melted to form spherical droplets with a giant fullerene structure [9], and eventually anvils themselves could be heated to diamond melting temperatures without anything dark being present [10].

We accomplished a great deal of research on a variety of phases, nearly all believed to be components of planetary interiors, and attended many conferences during the $\sim$ ten years that Taro and I worked together. We had some very talented students: Ho-Kwang (Dave) Mao, who has become one of the leading researchers in mineral physics, is a member of the National Academy of Sciences, and founded HPSTAR, a new research institute in China patterned after Carnegie's Geophysical Laboratory. Lin-gun (John) Liu joined Ted Ringwood's Lab in Canberra, Australia. A few months later, Ted visited me in Rochester and told me that John had just successfully synthesized and identified the first silicate perovskite phase [11]. Ted was convinced that it was the so-called "post-spinel" phase, a phase that soon came to be considered the most abundant mineral in the Earth. It was not found as a naturally occurring phase until 2014, when it was given the mineral name bridgmanite in honor of Percy Bridgman [12].

After 2 years at Alfred and 7 years at Rochester, Taro took a sabbatical at Caltech working with Don Anderson and Tom Ahrens. After that, he felt he had accomplished what he had told Doc Ewing he wanted to do concerning the Earth's interior by finding ways to determine physical properties such as crystal structures, densities, and compressibilities that surely influence the velocities of seismic signals, as well as ways to solve compositions based on those physical properties at high pressures. He decided that the time had come to return to his geochemical research at Lamont Geological Observatory, just as he had told Doc he would do. Amazingly, while at Rochester, Taro had remotely continued his carbon dioxide research with Wally Broecker at Lamont.

Taro had, indeed, been instrumental in launching a new field which soon came to be known as mineral physics thanks to Orson Anderson and Ed Schreiber. I missed Taro and Elaine as friends and colleagues, but continued my interest in mineral physics, moving to Cornell University where there was the Cornell High Energy Synchrotron Source (CHESS), which soon proved to be one of the most important new technologies for conducting research in our new field of study.

Taro's suggestion of laser heating had opened a new realm of research into examination of the properties of minerals deep in the Earth's interior, eventually leading researchers all the way to the pressure-temperature conditions in the Earth's core, and even the interiors of larger planets. Diamond anvil cells and multi-anvil devices have evolved side by side over the decades following the 1960s, each filling increasingly diverse needs. Nothing can compare to the multi-anvil devices when sample size matters, or the synthesis of new phases is needed for further testing. However, it is hard to beat the diamond anvil cells if the experimenter wants to travel to a different lab or conference with a sample 
already under high-pressure and easily slipped into a suitcase or a pocket. In the decades that followed, some giant advances in technology have motivated users to find ways to use them. Synchrotron sources along with digital methods for recording X-ray patterns now provide such small, intense X-ray beams and rapid imaging that exposures which used to require a week can now be made in seconds and, in some cases, fractions of seconds, making it possible to record a movie of a phase transition or a chemical reaction. Synchrotron radiation also made it possible to introduce a range of spectroscopic techniques that could yield information never before possible. I hope that my descriptions, along with Bob Liebermann's descriptions of the early days of mineral physics at Lamont, will further motivate newcomers to explore ways to delve even more deeply as technology advances [1].

Taro, who passed away on 3 December 2019, will be sorely missed by all of us who knew him. It was an honor to have had the chance to work so closely with such a remarkable and versatile research scientist, with such a keen mind and such great ideas. If it had not been for Taro, I might never have joined such a fascinating branch of science at the time of its inception.

Acknowledgments: I especially want to thank Bob Liebermann for inviting me to tell this story about Taro Takahashi's lesser-known contributions to one of today's most active new branches of science. I appreciate the help given to me by my friend, Elise Skalwold, in helping me prepare this paper.

Conflicts of Interest: The authors declare no conflict of interest.

\section{Appendix A}

List of Peer Reviewed Papers by Takahashi, Bassett, and Students:

- $\quad$ Bassett, W.A.; Takahashi, T. Specific volume measurements of crystalline solids at pressures up to 200 kilobars by X-ray diffraction, In 1964 Symposium on High-pressure Technology; Giardini, A.A., Lloyd, E.C., Eds.; American Society of Mechanical Engineers: New York, NY, USA, 1964; pp. 1-7.

- Bassett, W.A.; Takahashi, T. Silver iodide polymorphs. Am. Miner. 1965, 50, 1576-1594.

- Bassett, W.A.; Takahashi, T.; Stook, P. X-ray diffraction and optical observations on crystalline solids up to 300 kilobars. Rev. Sci. Instrum. 1967, 38, 37-42.

- Mao, H.K.; Bassett, W.A.; Takahashi, T. Effect of pressure on crystal structure and lattice parameters of iron up to 300 kilobars. J. Appl. Phys. 1967, 38, 272-276.

- Takahashi, T.; Bassett, W.A. The effect of pressure on the density of possible mantle-core minerals up to 300 kilobars, In U.S. Progress Report, International Upper Mantle Project; National Academy of Sciences, 1967; pp. 134-136.

- $\quad$ Bassett, W.A.; Takahashi, T.; Mao, H.K.; Weaver, J.S. Pressure-induced phase transformation in NaCl. J. Appl. Phys. 1968, 39, 319-325.

- Takahashi, T.; Bassett, W.A.; Mao, H.K. Isothermal compression of the alloys of iron up to 300 kilobars at room temperature: Iron-nickel alloys. J. Geophys. Res. 1968, 73, 4717-4725.

- Mao, H.K.; Takahashi, T.; Bassett, W.A.; Weaver, J.S.; Akimoto, S. Effect of pressure and temperature on the molar volumes of wustite and three $(\mathrm{Fe}, \mathrm{Mg})_{2} \mathrm{SiO}_{4}$ spinel solid solutions, J. Geophys. Res. 1969, 74, 1061-1069.

- Takahashi, T.; Mao, H.K.; Bassett, W.A. X-ray diffraction study of a high pressure polymorph of lead, Science 1969, 165, 1352-1353.

- Bassett, W.A.; Takahashi, T.; Campbell, J.K. Volume changes for the B1-B2 phase transformations in three potassium halides at room temperature, Trans. Am. Crystallographic Assoc. 1969, 5, 93-103.

- Mao, H.K.; Takahashi, T.; Bassett, W.A. Isothermal compression of the spinel phase of $\mathrm{Ni}_{2} \mathrm{SiO}_{4}$ up to 300 kilobars at room temperature, Phys. Earth Planet. Interiors 1970, 3, 51-53.

- Takahashi, T.; Liu, L.G. Compression of ferromagnesian garnets and the effects of solid solutions on the bulk modulus. J. Geophys. Res. 1970, 75, 5757-5766.

- $\quad$ Liu, L.G.; Takahashi, T.; Bassett, W.A. Effect of pressure and temperature on the lattice parameters of rhenium. J. Phys. Chem. Solids 1970, 31, 1345-1351. 
- Mao, H.K.; Bassett, W.A.; Takahashi, T. High pressure phase transformation in magnetite. Annu. Rep. Dir. Geophys. Lab. 1970, 68, 249-250.

- Mao, H.K.; Takahashi, T.; Bassett, W.A. Study of lead up to 180 kilobars. Annu. Rep. Dir. Geophys. Lab. 250-253.

- Weaver, J.S.; Takahashi, T.; Bassett, W.A. Calculation of the P-V relation for sodium chloride up to 300 kilobars at $25^{\circ} \mathrm{C}$, In Accurate Characterization of the High-Pressure Environment: Proceedings; Lloyd, E.C., Ed.; US National Bureau of Standards: Gaithersburg, MD, USA, 1971; pp. 189-199.

- Bassett, W.A.; Takahashi, T. Effect of pressure on possible mantle minerals up to 300 kilobars; In Upper Mantle Project; National Research Council of the National Academies (NRC), 1971; pp. 181-183.

- Liu, L.G.; Bassett, W.A.; Takahashi, T. Effect of pressure on lattice parameters of stishovite. J. Geophys. Res. 1974, 79, 1160-1164.

- Mao, H.K.; Takahashi, T.; Bassett, W.A.; Kinsland, G.L.; Merrill, L. Isothermal compression of magnetite to $320 \mathrm{kbar}$ and pressure-induced phase transformation. J. Geophys. Res. 1974, $79,1165-1170$.

- Liu, L.G.; Bassett, W.A.; Takahashi, T. Isothermal compressions of a spinel phase of $\mathrm{Co}_{2} \mathrm{SiO}_{4}$ and magnesian ilmenite. J. Geophys. Res. 1974, 79, 1171-1174.

- Bassett, W.A.; Takahashi, T. X-ray diffraction studies up to 300 kilobars. In Advances in High Pressure Research; Wentorf, R., Ed.; Academic Press London and New York, 1974; Volume 4, pp. 165-247.

\section{References}

1. Liebermann, R.C. Multi-anvil, high pressure apparatus: A half-century of development and progress. High Press. Res. 2011, 31, 493-532. [CrossRef]

2. Bassett, W.A. Diamond Anvil Cell, 50th Birthday. High Press. Res. 2009, 29, 163-186. [CrossRef]

3. Bassett, W.A.; Takahashi, T.; Stook, P. X-ray diffraction and optical observations on crystalline solids up to 300 kilobars. Rev. Sci. Instrum. 1967, 38, 37-42. [CrossRef]

4. Bassett, W.A. The diamond cell and the nature of the Earth's mantle. Ann. Rev. Earth Planet. Sci. 1979, 7, 357-384. [CrossRef]

5. Takahashi, T.; Bassett, W.A.; Mao, H.K. Isothermal compression of the alloys of iron up to 300 kilobars at room temperature: Iron-nickel alloys. J. Geophys. Res. 1968, 73, 4717-4725. [CrossRef]

6. Mao, H.K.; Takahashi, T.; Bassett, W.A.; Weaver, J.S.; Akimoto, S. Effect of pressure and temperature on the molar volumes of wustite and three $(\mathrm{Fe}, \mathrm{Mg})_{2} \mathrm{SiO}_{4}$ spinel solid solutions. J. Geophys. Res. 1969, 74, 1061-1069. [CrossRef]

7. Liu, L.G.; Bassett, W.A.; Takahashi, T. Isothermal compression of a spinel phase of $\mathrm{Co}_{2} \mathrm{SiO}_{4}$ and magnesian ilmenite. J. Geophys. Res. 1974, 79, 1171-1174. [CrossRef]

8. Takahashi, T.; Liu, L.G. Compression of ferromagnesian garnets and the effect of solid solutions on the bulk modulus. J. Geophys. Res. 1970, 75, 5757-5766. [CrossRef]

9. Bassett, W.A.; Weathers, M.S. Fullerene structures produced from melted diamond at high pressure by laser heating. In Proceedings of the 1993 AIRAPT Conference in Colorado Springs; American Institute of Physics: Melville, NY, USA, 1994; pp. 651-653.

10. Gold, J.S.; Bassett, W.A.; Weathers, M.S.; Bird, J.M. Melting of diamond. Science 1984, 225, 921-922. [CrossRef] [PubMed]

11. Liu, L. Silicate Perovskite from Phase Transformation of Pyrope-Garnet at High Pressure and Temperature. Geophys. Res. Letters 1974, 1, 277-280. [CrossRef]

12. Tschauner, O.; Ma, C.; Beckett, J.R.; Prescher, C.; Prakapenka, V.B.; Rossman, G.R. Discovery of bridgmanite, the most abundant mineral in Earth, in a shocked meteorite. Science 2014, 346, 1100-1102. [CrossRef] [PubMed] 